\title{
Corneal reconstruction by stem cells and bioengineering
}

This article was published in the following Dove Press journal:

Clinical Ophthalmology

3 September 2012

Number of times this article has been viewed

\section{Olli Arjamaa}

Department of Biology, University of Turku, Turku, Finland
Correspondence: Olli Arjamaa

Department of Biology,

Vesilinnanmäki, 20014 University

of Turku, Turku, Finland

Tel +358405I25452

Email olli.arjamaa@utu.fi
Abstract: Almost 300 million people are visually impaired worldwide due to various eye diseases such as cataracts, glaucoma, age-related macular degeneration, diabetic retinopathy, and corneal diseases. Notably, ten million people are blind because of severe ocular surface diseases and the majority of cases occur in developing countries. Blinding ocular surface diseases have, however, become treatable by grafting of surface layers, or by full-thickness transplantation of the cornea. As the demand for human corneal tissue for surface reconstruction and transplantation far exceeds the supply, methods are being developed to supplement tissue donation. Xenotransplantation of the cornea or cells from genetically modified pigs may become one of the solutions. Transplantation of limbal stem cells within tissue biopsies, to restore the transparency of the cornea is another remarkable method, which has shown its potential in several clinical studies. The combination of stem cell technology and engineering of biocompatible tissue equivalent, still at preclinical stage, has shown us how synthetic corneal tissue is able to guide cultured corneal stromal stem cells of human origin, to become native-like stroma, the most important layer of the cornea. These findings give hope for a large-quantity production of biomaterial for corneal reconstruction. As such, clinical ophthalmologists should become more familiar with the methods of laboratory science.

Keywords: eye, grafting, keratoplasty, xenotransplantation, cell reservoir, biocompatible tissue equivalent

\section{Introduction}

Approximately 285 million people are visually impaired worldwide and among the eye diseases causing the problem are cataract, glaucoma, age-related macular degeneration, diabetic retinopathy and corneal diseases. ${ }^{1}$ While a growing and evolving number of treatment modalities have become available for these diseases (cataract surgery, topical drug medication, intravitreal antivascular endothelial growth factor injection, and laser photocoagulation), ten million people are blind due to severe ocular surface diseases. ${ }^{2}$ Trauma, bacterial (often Chlamydia trachomatis) and viral infections, or heritable diseases are able to irreversibly compromise the transparency of the cornea, the outermost part of the eye. ${ }^{2}$ A significant proportion of blind people will need tissue-based repair: either grafting of surface layers of the opaque cornea with healthy endothelium or, in more severe cases, a full-thickness transplantation of the five main layers of cornea by means of penetrating keratoplasty. In the anterior lamellar keratoplasty procedure, the diseased layers of the cornea, consisting of varying amount of stroma, will be removed and replaced, while the Descemet's membrane and the endothelium remain intact. In endothelial keratoplasty, the endothelium and the Descemet's membrane are replaced with a graft. In addition, there are newer variations 
of keratoplasty being developed to treat an endothelial disease. ${ }^{3}$ In the USA, 42,700 corneal transplantation were done in 2010 and almost half of corneal transplantations were of endothelial keratoplasty type while 5 years earlier the figure was as low as 5\%. ${ }^{3}$ However, as the current demand for human corneal cells and tissue for ocular surface reconstruction and transplantation far exceeds the supply, ${ }^{4,5}$ other cellular sources for transplantation are being sought, and biosynthetic alternatives are being developed. In addition, the long-term survival rate of corneal transplantation or keratoplasty may be quite variable at times, and transplants need long-lasting medication and follow-up. Xenotransplantation of cornea or cells from genetically modified pigs (which have been successfully transplanted into primates) is a novel surgical path to follow and may become one of the next steps in a series of evolutionary medical procedures. ${ }^{6}$ In developing countries where corneal scarring is very common due to infections and where the waiting lists for corneal transplantation are long, xenotransplantation could be one of the solutions.

\section{Stem cells}

The limbus, a narrow zone (1-2 $\mathrm{mm})$ between the cornea and the bulbar conjunctiva, provides a physiological stem cell reservoir to keep the corneal epithelium clear. For over 100 years, ophthalmologists removing corneal foreign bodies under a slit-lamp or a biomicroscope have unwittingly seen how stem cells migrate and differentiate to repair small corneal defects; in these cases, it takes only two days for damaged epithelial cells to be restored to their normal structure. Limbal epithelial stem cells can be transplanted within tissue biopsies using various surgical techniques. To date, it has not been possible to definitely identify and cultivate stem cells from corneal or limbal epithelial cells, although there are many candidate markers for stem or progenitor cells that still require further investigation..$^{5}$ In severe cases of bilateral ocular surface disease, the limbus may have been almost totally destroyed and therefore, other reservoirs apart from the limbus must be found to provide ophthalmologic surgeons with transplantable stem cells. The epithelium from conjunctiva or oral mucosa, cutaneous epithelium, mesenchymal, and embryonic and fetal stem cells can all be utilized as an alternative source of cells to repair corneal epithelia. ${ }^{4}$ However, the most promising results that have been achieved were grafts containing autologous limbal stem cells in patients with burn-related limbal stem deficiency in one eye. In the study of Rama et al, ${ }^{7}$ autologous limbal stem cells were obtained by means of biopsy from the contralateral unaffected eye, and the cells were then cultured ex vivo on fibrin. A total of 125 cultures were grafted in 113 eyes and the limbal stem-cell transplantation was judged successful in $76.6 \%$ of the eyes, with restored eyes having a transparent cornea and renewing corneal epithelium; restored eyes remained stable up to 10 years of follow-up. Marchini et $\mathrm{al}^{8}$ grafted autologous ex vivo-cultured limbal stem cells in sixteen eyes with severe unilateral stem cell deficiency caused by chemical burns. Limbal stem cells were isolated from biopsies and cultivated onto feeder layers of lethally-irradiated murine cells for 7-10 days, and then plated on fibrin glue discs for an additional 7-10 days. The percentage of corneal and conjunctival epithelial cells was evaluated by means of antibodies against a group of stem cell markers. Finally, limbal stem cell sheets were grafted onto damaged corneas. In this study, at 12 months after surgery, $63 \%$ of patients had a stable and clear epithelium, 19\% had partially successful surgery, and a graft failure occurred in $19 \%$ of the patients.

Despite these advancements, there is a great need for a tissue-engineered alternative to treat irreversible corneal damage.

Although ophthalmologists wishing to utilize embryonic stem cells are faced with moral, legal, religious, and scientific challenges, stem cell technology is being experimentally capitalized in end-stage, age-related macular degeneration. Clinical trials have started, in which dysfunctional retinal pigment epithelium have been replaced with functional retinal pigment epithelium generated from embryonic stem cells. ${ }^{9,10}$

\section{Bioengineering}

One solution to provide clinicians with sufficient material to restore corneal transparency may lie in the combination of stem cell technology and the engineering of biocompatible tissue equivalent. Fagerholm and colleagues ${ }^{11}$ conducted a phase 1 clinical study in which they implanted biosynthetic mimics of corneal extracellular matrix in ten patients, to replace the opaque anterior cornea without the use of any human donor tissue. The patients under study suffered from keratoconus or corneal scarring. The researchers used collagen, which is amenable to modification, as a starting material. The collagen was first synthetically cross-linked, and molded into a biosynthetic implantable corneal substitute, which was cell-free. Then, by means of recombinant collagen, a class of lamellar implants was produced which relied on the function of host cells, thereby avoiding the rejection reaction. After a 24-month follow-up, 
the biosynthetic implants remained avascular without the need for long-term use of steroid immunosuppression. Both the tear film and the touch sensitivity were restored; if these cannot be achieved the corneas will lose their transparency again. This was the first time that an artificial device stimulated endogenous corneal regeneration with touch sensation, tear film, and normal eye pressure. ${ }^{12}$

The preclinical in vitro study of $\mathrm{Wu}$ and colleagues ${ }^{13}$ is a remarkable example of how bioengineered corneal tissue can guide cultured corneal stromal stem cells of human origin to become native-like stroma, with an identical alignment of collagen matrix. A strong and transparent stroma of the cornea is the most critical layer when the aim is to produce a fully bioengineered cornea. In this study, synthetic polyester urethane urea was used as a substrate which induced human corneal stem cells to elongate and align into the keratocytic phenotype, and which were then able to generate stromal tissue. This "bottom-up strategy," as the authors call it, in which synthetic material gives structural cues to stem cells as to which direction to differentiate into, opens up a new avenue for corneal repair and regression.

What is the role of production of biosynthetic corneas in the future? Although there are many problems to be solved, a combination of stem cell technology and bioengineering may be able to supplement the supply of donor corneas in the near future, once the biomaterial for corneas can be safely produced in large quantities.

Biological reconstruction of the cornea is an amazing interface where laboratory biological science can potentially meet the demand of a clinically relevant problem in a clinical setting. This will eventually lead to a legally blind individual seeing once more. As such, clinical ophthalmologists should become more familiar with the emerging and current methods of laboratory science in reparative techniques of corneal pathology.

\section{Disclosure}

The author reports no conflicts of interest in this work.

\section{References}

1. Focusing on ophthalmology [editorial]. Lancet. 2012;379(9827):1678.

2. Whitcher JP, Srinivasan M, Upadhyay MP. Corneal blindness: a global perspective. Bull World Health Organ. 2001;79(3):214-221.

3. Tan DT, Dart JK, Holland EJ, Kinoshita S. Corneal transplantation. Lancet. 2012;379(9827):1749-1761.

4. Di Girolamo N. Stem cells of the human cornea. Br Med Bull. 2011;100:191-207.

5. Nakamura T, Kinoshita S. New hopes and strategies for the treatment of severe ocular surface disease. Curr Opin Ophthalmol. 2011;22(4): 274-278.

6. Ekser B, Ezzelarab M, Hara H, et al. Clinical xenotransplantation: the next medical revolution? Lancet. 2012;379(9816):672-683.

7. Rama P, Matuska S, Paganoni G, Spinelli A, De Luca M, Pellegrini G. Limbal stem-cell therapy and long-term corneal regeneration. New Engl J Med. 2010;363(2):147-155.

8. Marchini G, Pedrotti E, Pedrotti M, et al. Long-term effectiveness of autologous cultured limbal stem cell grafts in patient with limbal stem cell deficiency due to chemical burns. Clin Experiment Ophthalmol. 2012;40(3):255-267.

9. Bull ND, Martin KR. Concise review: toward stem cell-based therapies for retinal neurodegenerative diseases. Stem Cells. 2011;29(8): $1170-1175$.

10. Schwartz SD, Hubschman JP, Heilwell G, et al. Embryonic stem cell trials for macular degeneration: a preliminary report. The Lancet. 2012;379(9817):713-720.

11. Fagerholm P, Lagali NS, Merrett K, et al. A biosynthetic alternative to human donor tissue for inducing corneal regeneration: 24-month follow-up of a phase 1 clinical study. Sci Transl Med. 2010;2(46): 46ra61.

12. Lagali N, Fagerholm P, Griffith M. Biosynthetic corneas: prospects for supplementing the human donor cornea supply. Expert Rev Med Devices. 2011;8(2):127-130.

13. Wu J, Du Y, Watkins SC, Funderburgh JL, Wagner WR. The engineering of organized human corneal tissue through the spatial guidance of corneal stromal stem cells. Biomaterials. 2012;33(5):1343-1352.
Clinical Ophthalmology

\section{Publish your work in this journal}

Clinical Ophthalmology is an international, peer-reviewed journal covering all subspecialties within ophthalmology. Key topics include: Optometry; Visual science; Pharmacology and drug therapy in eye diseases; Basic Sciences; Primary and Secondary eye care; Patient Safety and Quality of Care Improvements. This journal is indexed on Submit your manuscript here: http://www.dovepress.com/clinical-ophthalmology-journal

\section{Dovepress}

PubMed Central and CAS, and is the official journal of The Society of Clinical Ophthalmology (SCO). The manuscript management system is completely online and includes a very quick and fair peer-review system, which is all easy to use. Visit http://www.dovepress.com/ testimonials.php to read real quotes from published authors. 